\title{
Genetic risk factors for respiratory diseases of preterm infants
}

\author{
Friederike Pagel $^{1^{*}}$, Sarah Leick${ }^{1}$, Michael Preuß², Christoph Härtel ${ }^{1}$, Egbert Herting ${ }^{1}$, Wolfgang Göpel ${ }^{1}$ \\ From 50th Workshop for Pediatric Research \\ Göttingen, Germany. 20-21 March 2014
}

\begin{abstract}
Aims
Genetic variants of pulmonary surface glycoproteins like Muc5a and Muc5b are known to affect mucociliary clearance, control of infections and maybe associated with pulmonary fibrosis [1-3]. We tested the hypothesis that Muc5b (rs35705950) is associated with bronchopulmonary dysplasia (BPD) in mechanically ventilated preterm infants. In addition, we aimed to identify common variants associated with the need for surfactant treatment.
\end{abstract}

\section{Methods}

Preterm infants with a birth weight below 1500 grams born in the GNN were genotyped for rs35705950 $(\mathrm{n}=8029)$. Furthermore, 1272 infants were chip-genotyped (AXIOM genome wide array, GWA), and candidate polymorphisms were replicated in two additional groups of preterm infants $(n=3839$ and $n=2830)$.

\section{Results}

Frequencies for rs35705950 were in the expected range (GG $82 \%$, GT 17\%, TT 1\%). The GT/TT-genotype was a strong genetic risk factor for the development of BPD in ventilated infants with sepsis (OR $5.795 \% \mathrm{CI} 2-15 ; \mathrm{p}=4.2 \mathrm{x}$ $10^{-5}$ ). In GWA, we identified 10 candidate polymorphisms however, only one minor allele proved to be associated with a reduced need for surfactant treatment in preterm infants (OR 0.7, 95\%CI 0.6-0.8, $\mathrm{p}=3.8 \times 10^{-8}$ corrected for gestational age).

\section{Conclusion}

Common polymorphisms are associated with respiratory disease in preterm infants. Our data indicate that personalized treatment stratified for genetic factors might be a useful approach for future therapy in neonates.

'Department of Paediatrics, University of Lübeck, UKSH, 23538 Lübeck, Germany

Full list of author information is available at the end of the article

\section{Note}

Wolfgang Göpel for the German Neonatal Network (GNN).

\section{Authors' details}

'Department of Paediatrics, University of Lübeck, UKSH, 23538 Lübeck, Germany. ${ }^{2}$ Institute of Medical Biometry and Statistics, University of Lübeck, 23538 Lübeck, Germany.

Published: 11 September 2014

References

1. Fahy JV: N Engl J Med 2010, 363:2233-47.

2. Roy MG, et al: Nature 2014, 505:412-6.

3. Seibold MA, et al: N Engl J Med 2011, 364:1503-12

doi:10.1186/2194-7791-1-S1-A3

Cite this article as: Pagel et al:: Genetic risk factors for respiratory

diseases of preterm infants. Molecular and Cellular Pediatrics 2014

1(Suppl 1):A3

\section{SpringerOpen ${ }^{\circ}$}

(C) 2014 Pagel et al; licensee Springer This is an Open Access article distributed under the terms of the Creative Commons Attribution License (http://creativecommons.org/licenses/by/2.0), which permits unrestricted use, distribution, and reproduction in any medium, provided the original work is properly cited.
Submit your manuscript to a SpringerOpen ${ }^{\circ}$ journal and benefit from:

- Convenient online submission

- Rigorous peer review

- Immediate publication on acceptance

- Open access: articles freely available online

- High visibility within the field

- Retaining the copyright to your article

Submit your next manuscript at $>$ springeropen.com 